\title{
Nitrate and silicic acid in the world ocean: patterns and processes
}

\author{
Daniel Kamykowski \& Sara-Joan Zentara \\ Department of Marine, Earth \& Atmospheric Sciences, Box 8208, North Carolina State University, Raleigh, \\ North Carolina 27695, USA
}

\begin{abstract}
Two world ocean data sets, GEOSECS and NODC, were analyzed for patterns in the nitrate versus silicic acid regression relation. Significant regional nitrate or silicic acid excesses (i.e. amount of one of these plant nutrients remaining in the water after the other is no longer measurable) tend to occur in some areas of upwelling, shallow sills, deep convection or high rainfall/river outflow. The Southern Ocean is unique in the intensity and complexity of projected (regression intercepts on the nitrate $[y]$ or silicic acid $[x]$ axis] excesses. These global nutrient depletion patterns pertain to regional comparisons of phytoplankton succession and thus to the overall character of plankton community structure. Intercept patterns in different areas are affected by the processes that determine absolute nutrient concentrations at the beginning, and their relative decline during, the growth season. The region south of the southern Polar Front is unique because winter nutrient concentrations are unusually high around Antarctica due to water mass characteristics and because nutrients generally remain unusually abundant over the growth season partly in response to the cycle of incident solar radiation. The patterns in the regression intercepts in this region largely result from variations in the regression slopes which respond to different weightings of the chemical and biological pathways that determine nitrate and silicic acid concentrations in the upper water column. The nitrate and silicic acid profiles in the Southern Ocean contain information on the temporal average of primary production and of nitrogen recycling up to the time of sample collection within the growth season. The interpretation of this information depends on the detail to which the processes that determine the water column concentrations of nitrate and silicic acid are known.
\end{abstract}

\section{INTRODUCTION}

Several studies of limited geographic extent have discussed temporal and/or spatial variations in the upper ocean relations between nitrate and silicic acid concentrations including accounts of which plant nutrient becomes unmeasurable first as the growth season progresses. The represented areas include Peru (Dugdale 1972, Friederich \& Codispoti 1981), Northwest Africa (Friederich \& Codispoti 1979, Minas et al. 1982), Southwest Africa (Andrews \& Hutchings 1982), Southern California (Kamykowski 1974), the Polar Front (Walsh 1971) and a Southern Ocean transect (Le Corre \& Minas 1983). Except for Southern California, these locations are often characterized by silicic acid depletion in the presence of excess nitrate that is considered a consequence of diatom growth.

Zentara \& Kamykowski (1977) have used a broader geographic approach to examine regional near-surface patterns in the relation between nitrate and silicic acid concentrations. Along the west coasts of North and
South America, silicic acid excess (i.e. the amount of silicic acid remaining in the water) at nitrate depletion generally increases with distance north of the equator and nitrate excess at silicic acid depletion generally increases with distance south of the equator. The major upper-ocean current systems affect the rate at which silicic acid or nitrate excess changes with latitude and the exact equatorial symmetry of these changes. Harrison et al. (1981) have refined this generalization near the equator off the coast of Peru based on nonlinear nutrient relations with depth. Zentara \& Kamykowski (1981) have further examined the Southern Hemisphere nutrient patterns in the Pacific Ocean. Although South Pacific Central Water exhibits nearly simultaneous nitrate and silicic acid depletion, the water south of the Subtropical Convergence generally exhibits a potential for nitrate excess at silicic acid depletion. Unexpectedly, the waters south of the Antarctic Divergence exhibit silicic acid excess (Ross Sea Water) at nitrate depletion.

These various reports verify that upper ocean nitrate 
(N) and silicic acid (Si) concentrations generally exhibit a complex spatial pattern in nutrient ratio (i.e. $\mathrm{N} / \mathrm{Si}$ ) emulating that found in the deep ocean (Sverdrup et al. 1942, Broecker \& Li 1970). In order to further examine the near-surface pattern in the relation between these 2 plant nutrients beyond the listed local or regional observations, a generalized survey of global data bases was undertaken. The precedent for using a multi-year data base collected by diverse ships derives from descriptive physical oceanography. Warren (1981) and Worthington (1981) have discussed the power and limits of using property fields to describe water characteristics. Examples of this approach are the north-south temperature, salinity and oxygen profiles in the Atlantic by Wust (1935) and similar eastwest sections of temperature, salinity, oxygen and phosphate across the Pacific by Reid (1965). The present paper adopts this approach and extends it through a station-by-station application of least squares linear regression analysis to the nitrate versus silicic acid data. The results of this effort provide a description of how these 2 plant nutrients co-vary in the upper part of the world ocean. The Southern Ocean is the focus of a detailed discussion of mechanisms and implications because of its rich variability in the relation between nitrate and silicic acid concentrations and because of the downstream influence that the nutrient patterns generated in this region exercise on phytoplankton community structure (Zentara \& Kamykowski 1981)

\section{METHODS}

Data from oceanographic stations at which nitrate and silicic acid concentrations were determined in parallel were obtained from 2 sources: (1) Scripps Institution of Oceanography provided the GEOSECS data tapes (Craig \& Turekian 1980); (2) the National Oceanographic Data Center (NODC) provided a complete set (including determinations up to the mid1970's as of fall 1981) of data tapes in Station Data I format for their 10 ocean areas. Some but not all of the GEOSECS stations were contained in the NODC data base. The data from GEOSECS or for each NODC ocean area were successively copied on disk and converted to Statistical Analysis System (SAS Institute Inc. 1982) data sets containing selected variables to $500 \mathrm{~m}$ depth that were appropriate to the proposed analysis. These abbreviated data sets were printed and were examined to determine selection criteria based on year of collection (only post-1962 to minimize diversity of analytical technique), salinity, depth, and nitrate and silicic acid concentrations, that would allow a representative near-surface linear regression of nitrate $(\mathrm{y})$ versus silicic acid $(\mathrm{x})$ to be calculated. The resulting criteria provided in Table 1 were applied to the GEOSECS and NODC data sets.

Least squares linear regressions of nitrate versus silicic acid were computed for each station. The Model I linear regression procedure was applied with the realization that both nutrients were measured with error and that the analysis was thus subject to the reservations associated with a Model II regression (Sokal \& Rohlf 1981). For example, the intercept and slope estimates can be biased to various degrees. Considering the characteristics of the nitrate and silicic acid data, however, a Model I approach was considered adequate to yield the broad generalizations sought in this survey. Several circumstances supported this choice. The analyzed data segments were restricted to linear relations between nitrate and silicic acid using depth and low nutrient thresholds. These linear portions generally exhibited high correlations between nitrate and silicic acid concentrations and nearly the same results for intercept and slope irrespective of whether nitrate or silicic acid was the dependent variable. The lower quality data (analytical and data entry errors) that remained in the NODC data set after the application of selection criteria could result in quite different estimates of intercept and slope when the dependent variable was reversed. The effect of this type of error was minimized by eliminating low intercepts from consideration, gathering intercepts into groups based on $>10$ and $>20 \mu \mathrm{M}$ of nitrate or silicic acid concentrations, and using the high quality GEOSECS data base as a standard against which the NODC patterns could be judged. Because of the bias in the analysis, only the strongest or the historically corroborated patterns were considered reliable. The consistency of the resulting patterns testifies to the validity of the approach.

The stations included in the final data set met 2 additional criteria based on the regression analysis: (1) a slope $(\Delta \mathrm{N} / \Delta \mathrm{Si})$ between $10^{-6}$ and 10 to eliminate negative slopes and a few $(\sim 5)$ unusually high slopes; (2) a standard deviation for dependent variable (sigma) between $10^{-6}$ and 4 to eliminate trivial regression lines (i.e. sigma $=0$ ) and regression lines with excessive scatter. Stations with the higher values (nitrate $>10 \mu \mathrm{M} \mathrm{N}$ and silicic acid $>10 \mu \mathrm{M} \mathrm{Si}$ ) of positive $\mathrm{y}$ or $\mathrm{x}$ intercepts were individually surveyed to verify that the computed intercepts and slopes reasonably represented the nitrate versus silicic acid scatter plot trends. Stations that were poorly represented by the intercepts or slopes were eliminated from the data set. A total of 217 GEOSECS stations and 11,576 NODC stations survived the criteria.

Each station was represented by an output data set that contained latitude, longitude, y intercept, slope and sigma. To this array, the $\mathrm{x}$ intercept was added 
Table 1. General criteria used to yield a representative linear regression in different regions of the world ocean

\begin{tabular}{|c|c|c|c|c|c|c|c|}
\hline Ocean & Area & Latitude & Longitude & $\begin{array}{c}\text { Salinity } \\
\% 0\end{array}$ & $\begin{array}{c}\text { Depth } \\
\text { m }\end{array}$ & $\begin{array}{l}\mathrm{NO}_{3} \\
\mu \mathrm{M}\end{array}$ & $\begin{array}{c}\mathrm{Si}(\mathrm{OH})_{4} \\
\mu \mathrm{M}\end{array}$ \\
\hline \multirow[t]{12}{*}{ Pacific } & 1 & $90^{\circ} \mathrm{S}-60^{\circ} \mathrm{S}$ & $150^{\circ} \mathrm{E}-180^{\circ}-70^{\circ} \mathrm{W}$ & $\geqslant 30$ & $\leqslant 200$ & $\geqslant 2$ & $\geqslant 2$ \\
\hline & 3 & $60^{\circ} \mathrm{S}-30^{\circ} \mathrm{S}$ & & $\geqslant 30$ & $\leqslant 500$ & $\geqslant 2$ & $\geqslant 2$ \\
\hline & 3 & $30^{\circ} \mathrm{S}-10^{\circ} \mathrm{S}$ & & $\geqslant 30$ & $\leqslant 500$ & $\geqslant 0$ & $\geqslant 0$ \\
\hline & 6 & $10^{\circ} \mathrm{S}-0^{\circ}$ & & $\geqslant 30$ & $\leqslant 250$ & $\geqslant 0$ & $\geqslant 0$ \\
\hline & 7 & $10^{\circ} \mathrm{S}-0^{\circ}$ & & $\geqslant 30$ & $\leqslant 250$ & $\geqslant 0$ & $\geqslant 0$ \\
\hline & 6 & $0-30^{\circ} \mathrm{N}$ & & $\geqslant 30$ & $\leqslant 250$ & $\geqslant 0$ & $\geqslant 0$ \\
\hline & 7 & $0-30^{\circ} \mathrm{N}$ & & $\geqslant 30$ & $\leqslant 250$ & $\geqslant 0$ & $\geqslant 0$ \\
\hline & 6 & $30^{\circ} \mathrm{N}-60^{\circ} \mathrm{N}$ & & $\geqslant 30$ & $\leqslant 250$ & $\geqslant 2$ & $\geqslant 2$ \\
\hline & 7 & $30^{\circ} \mathrm{N}-60^{\circ} \mathrm{N}$ & & $\geqslant 30$ & $\leqslant 250$ & $\geqslant 2$ & $\geqslant 2$ \\
\hline & 6 & $60^{\circ} \mathrm{N}-70^{\circ} \mathrm{N}$ & & $\geqslant 30$ & $\leqslant 200$ & $\geqslant 0$ & $\geqslant 0$ \\
\hline & 7 & $60^{\circ} \mathrm{N}-63^{\circ} \mathrm{N}$ & & $\geqslant 30$ & $\leqslant 200$ & $\geqslant 0$ & $\geqslant 0$ \\
\hline & 10 & $70^{\circ} \mathrm{N}-90^{\circ} \mathrm{N}$ & $140^{\circ} \mathrm{E}-0^{\circ}-130^{\circ} \mathrm{W}$ & $\geqslant 28$ & $\leqslant 200$ & $\geqslant 0$ & $\geqslant 0$ \\
\hline \multirow[t]{9}{*}{ Atlantic } & 1 & $90^{\circ} \mathrm{S}-60^{\circ} \mathrm{S}$ & $70^{\circ} \mathrm{W}-0^{\circ}-20^{\circ} \mathrm{E}$ & $\geqslant 30$ & $\leqslant 200$ & $\geqslant 2$ & $\geqslant 2$ \\
\hline & 2 & $60^{\circ} \mathrm{S}-30^{\circ} \mathrm{S}$ & & $\geqslant 30$ & $\leqslant 500$ & $\geqslant 2$ & $\geqslant 2$ \\
\hline & 2 & $30^{\circ} \mathrm{S}-10^{\circ} \mathrm{S}$ & & $\geqslant 30$ & $\leqslant 500$ & $\geqslant 0$ & $\geqslant 0$ \\
\hline & 5 & $10^{\circ} \mathrm{S}-0^{\circ}$ & & $\geqslant 30$ & $\leqslant 500$ & $\geqslant 0$ & $\geqslant 0$ \\
\hline & 5 & $0^{\circ}-40^{\circ} \mathrm{N}$ & & $\geqslant 30$ & $\leqslant 500$ & $\geqslant 0$ & $\geqslant 0$ \\
\hline & 5 & $40^{\circ} \mathrm{N}-60^{\circ} \mathrm{N}$ & & $\geqslant 30$ & $\leqslant 250$ & $\geqslant 0$ & $\geqslant 0$ \\
\hline & 8 & $40^{\circ} \mathrm{N}-60^{\circ} \mathrm{N}$ & & $\geqslant 28$ & $\leqslant 250$ & $\geqslant 0$ & $\geqslant 0$ \\
\hline & 9 & $50^{\circ} \mathrm{N}-70^{\circ} \mathrm{N}$ & & $\geqslant 28$ & $\leqslant 250$ & $\geqslant 0$ & $\geqslant 0$ \\
\hline & 10 & $60^{\circ} \mathrm{N}-90^{\circ} \mathrm{N}$ & $130^{\circ} \mathrm{W}-0^{\circ}-140^{\circ} \mathrm{E}$ & $\geqslant 28$ & $\leqslant 200$ & $\geqslant 0$ & $\geqslant 0$ \\
\hline \multirow[t]{4}{*}{ Indian } & 1 & $90^{\circ} \mathrm{S}-60^{\circ} \mathrm{S}$ & $20^{\circ} \mathrm{E}-150^{\circ} \mathrm{E}$ & $\geqslant 30$ & $\leqslant 200$ & $\geqslant 2$ & $\geqslant 2$ \\
\hline & 4 & $60^{\circ} \mathrm{S}-30^{\circ} \mathrm{S}$ & & $\geqslant 30$ & $\leqslant 500$ & $\geqslant 2$ & $\geqslant 2$ \\
\hline & 4 & $30^{\circ} \mathrm{S}-0^{\circ}$ & & $\geqslant 30$ & $\leqslant 250$ & $\geqslant 0$ & $\geqslant 0$ \\
\hline & 4 & $0^{\circ}-30^{\circ} \mathrm{N}$ & & $\geqslant 30$ & $\leqslant 250$ & $\geqslant 0$ & $\geqslant 0$ \\
\hline
\end{tabular}

through reorganization of the regression equation. If $y=a+b x$, then when $y=0$ this equation reduced to $\mathrm{x}=-\mathrm{a} / \mathrm{b}$. In the following discussion, if the $\mathrm{y}$ intercept was positive, excess nitrate was projected to occur in the near-surface waters at silicic acid depletion. If the $x$ intercept was positive, excess silicic acid was projected to occur in the near-surface waters at nitrate depletion. Except for some high-latitude stations (i.e. 60 to $90^{\circ}$ ), the $\mathrm{y}$ or $\mathrm{x}$ intercepts generally fell near actually measured zero values of nitrate or silicic acid, respectively. Zentara \& Kamykowski (1981) have provided representative plots demonstrating the fit of the regression lines to nitrate versus silicic acid scatter plots.

In situations where the intercepts are projected to the $\mathrm{y}$ or $\mathrm{x}$ axis using the linear regression beyond the available data at a given station, extrapolation error may occur. Subjectively, the general linearity of the selected data in the upper water column and the general agreement of the extrapolated intercepts with those of nearby stations containing lower nutrient concentrations support the present choice of including these stations to provide a normalized baseline for inter-regional comparisons.

The station locations and the linear regression parameters are presented on Mercator or Stereographic projections generated by the Cartographic Automatic Mapping System, version IV-A (CAMIVA), used in association with World Data Bank I. In addition, the 10 th, 50th, and 90th percentiles are computed for $1^{\circ}$ bands of latitude for sectors of the Southern Ocean from the South Pole to $30^{\circ} \mathrm{S}$ for nitrate and silicic acid concentrations and for the linear regression slopes. These results are represented by smoothed cubic fits to these percentiles drawn over latitudinal point plots of the 50th percentile.

\section{RESULTS AND DISCUSSION}

Fig. 1 shows the pattern of regression intercepts on the nitrate or silicic acid axis for the GEOSECS stations that survived the selection criteria. According to these data, the regression intercepts range between nitrate concentrations less than $5 \mu \mathrm{MN}$ and silicic acid concentrations less than $10 \mu \mathrm{M}$ Si over most of the world ocean except south of the southern Subtropical Convergence. As shown by Zentara \& Kamykowski (1981) for the Pacific sector, the Southern Ocean north of the Antarctic Divergence exhibits a potential for nitrate excess above $15 \mu \mathrm{M} \mathrm{N}$ at silicic acid depletion in all sectors. The GEOSECS data does not extend far 

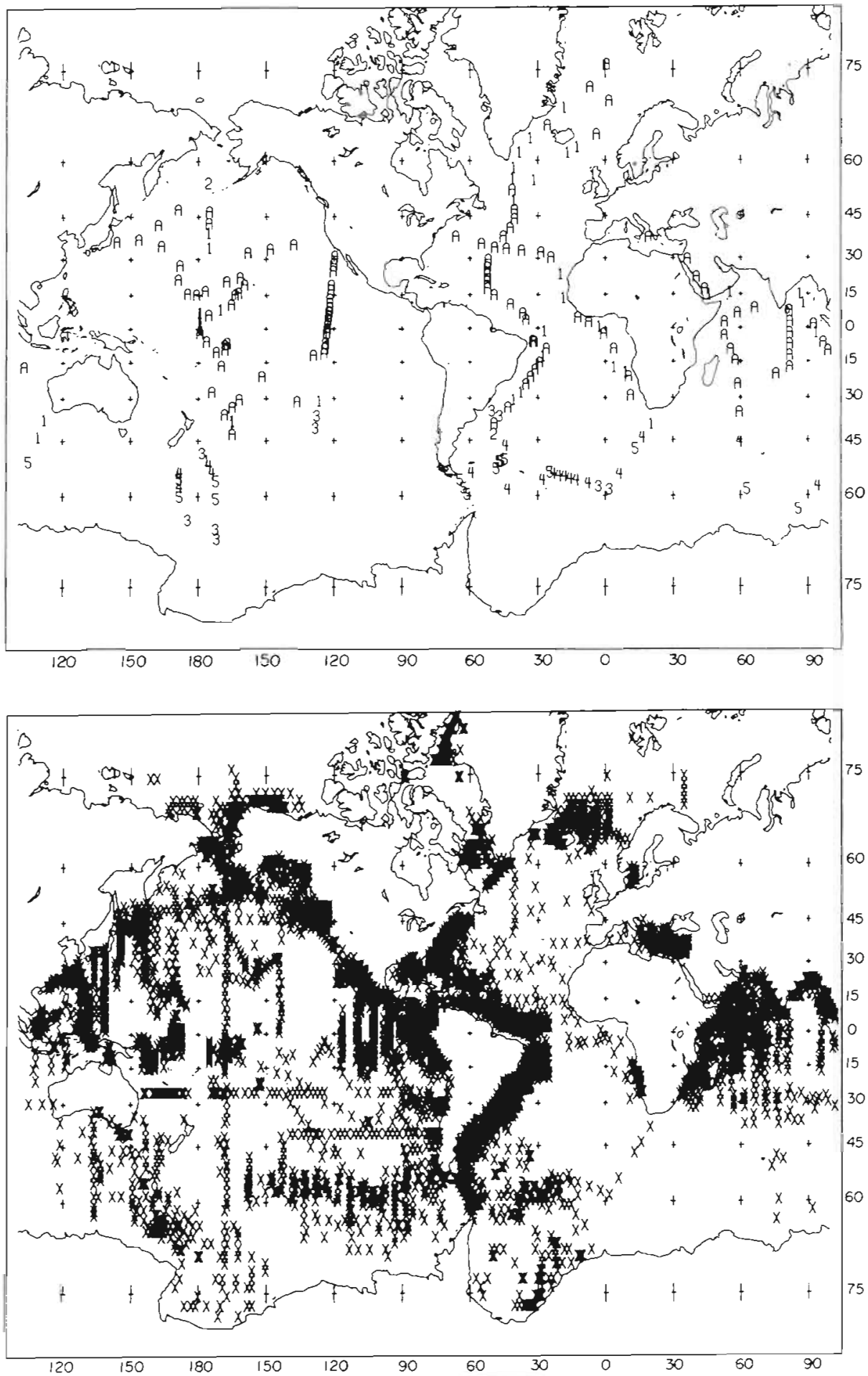

Fig. 1. World map of nitrate versus silicic acid regression intercepts for GEOSECS stations that survived selection criteria. Nitrate intercepts ( $\mathrm{y}$ axis) are represented by numbers from 1 to 5 for $5 \mu \mathrm{M}$ concentration intervals from 0 to $25 \mu \mathrm{M}$ and 6 for $>25 \mu \mathrm{M}_{i}$ silicic acid intercepts ( $\mathrm{x}$ axis) are represented by letters from $A$ to $E$ for $10 \mu \mathrm{M}$ concentration intervals from 0 to $50 \mu \mathrm{M}$ and $\mathrm{F}$ for $>50 \mu \mathrm{M}$

Fig. 2. World map of NODC stations that survived selection criteria

enough south to determine if silicic acid excess is projected at nitrate depletion south of the Antarctic Divergence (Zentara \& Kamykowski 1981). The GEOSECS data exhibit a tendency for silicic acid excess north of the equator and nitrate excess south of the equator, but the pattern is more complex than suggested by the western Pacific data discussed by
Zentara \& Kamykowski (1977). Fig. 1 shows that high quality data readily survive the applied selection criteria and provide a standard for the NODC data set. Due to the limited temporal and spatial coverage of the GEOSECS data set, only the most obvious geographic features in the central oceans are represented.

Fig. 2 provides a station distribution map for the 
NODC stations that passed the selection criteria. The NODC station distribution is more comprehensive but is still uneven with major gaps in the South Atlantic and South Indian Oceans and in the Arctic Sea. The former gap similarly occurs in the nitrate contour plots in the Southern Ocean Atlas (Gordon et al. 1982). Also, coastal regions are better represented compared to oceanic regions although some recent coastal data sets (post-1975) are not included. Fig. 2 should be considered when viewing later figures to identify the biases in the plots based on latitudinal averages and to identify the gaps in the world maps resulting from missing data.

Fig. 3 summarizes the pattern of regression inter-

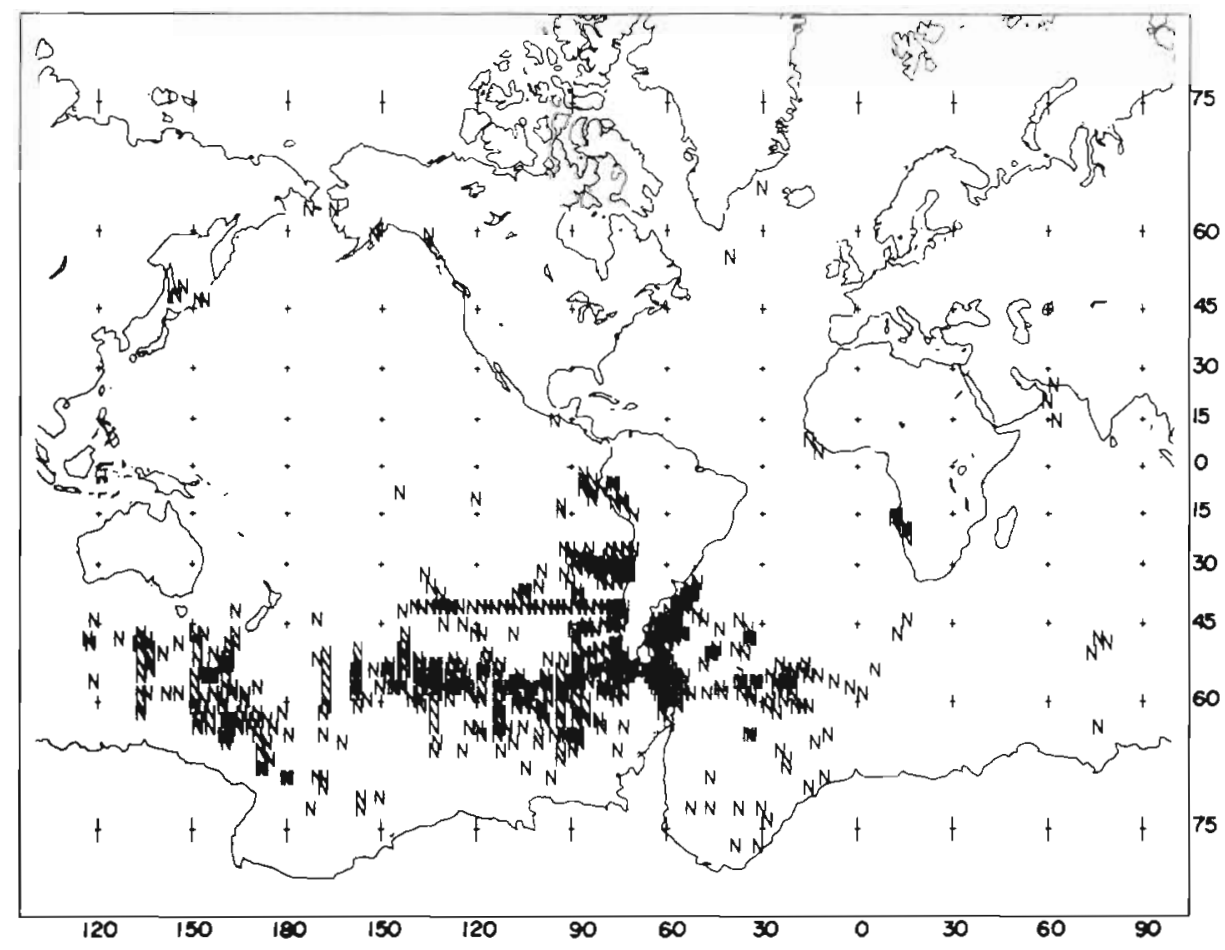

Fig. 3. World map of the nitrate versus silicic acid regression intercepts for NODC stations that survived selection criteria. Nitrate intercepts $>10 \mu \mathrm{M}$ are designated $\mathrm{N}$ (top) and silicic acid intercepts $>10 \mu \mathrm{M}$ are designated $\mathrm{S}$ (bottom)

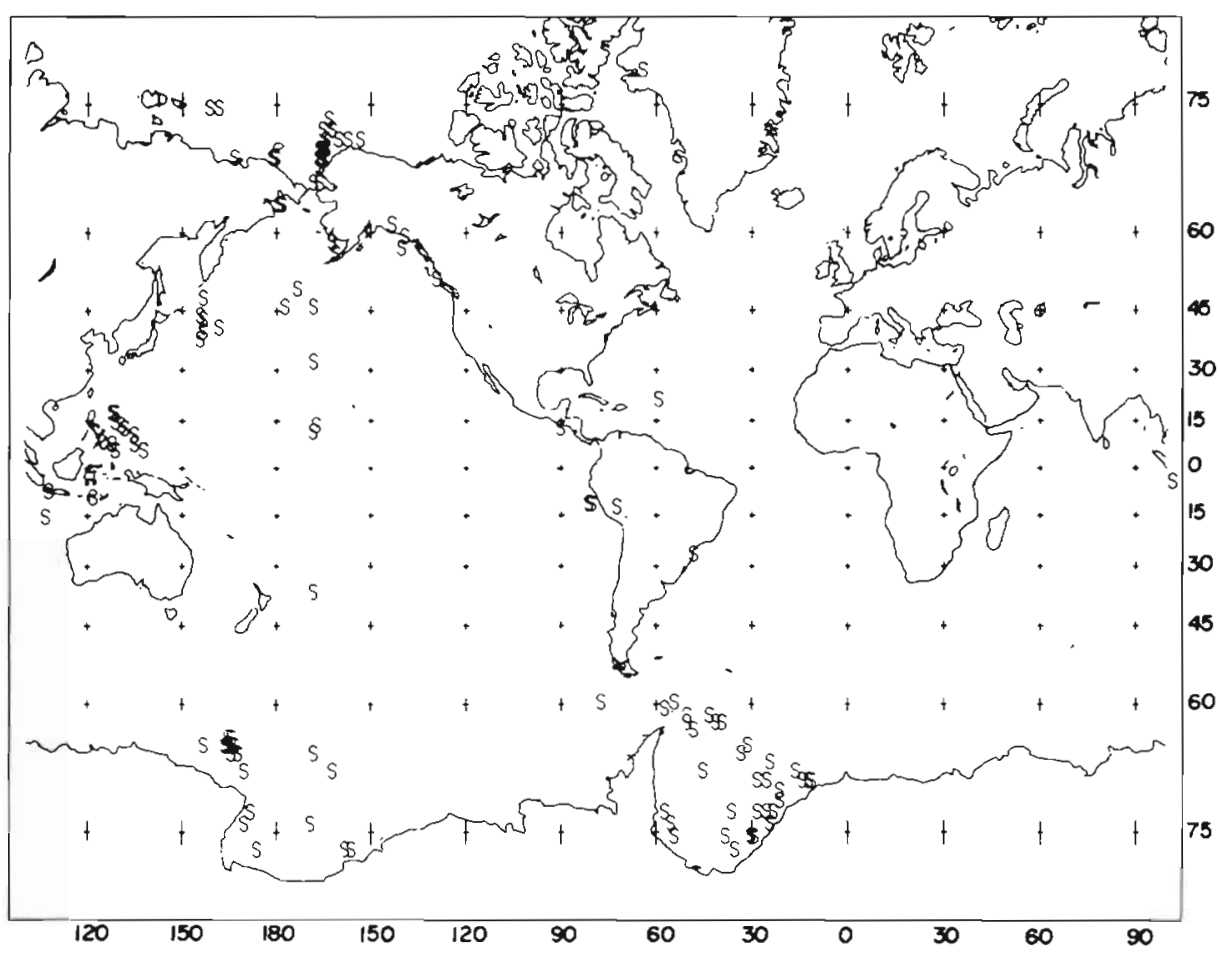


cepts for the NODC stations in Fig. 2 that exhibit nitrate (top map) or silicic acid (bottom map) excesses (i.e. the amount of nitrate or silicic acid remaining in the water after the other plant nutrient is no longer measurable) greater than $10 \mu \mathrm{M}$. This presentation does not necessarily mean that each of these regions is permanently characterized by this nutrient signature but only that a certain level of nutrient imbalance has been observed at some stations occupied within the area. The designated areas can be placed in different categories. Several of the isolated stations exhibiting either nitrate or silicic acid excess may be trivial measurements based on a few divergent local stations. From north to south, these include some of the nitrate excess regions in the North Atlantic, the nitrate and silicic acid excess regions off Central America and the subtropical North Atlantic, and the silicic acid excesses off South America and off New Zealand. An examination of the data from these stations, however, did not reveal any obvious errors. They, therefore, are included for completeness but should not be emphasized until verified in future nutrient determinations. The remaining regions exhibiting either nitrate or silicic acid excess are considered more reliable based on the greater number of observations or on the corroborating literature reports previously mentioned. The abundance of silicic acid in the North Pacific is a well-known feature due to the deep water circulation patterns in the world ocean (Berger 1970). The increased occurrence of silicic acid in Fig. 3 north of the GEOSECS stations in Fig. 1 add support to the gross nutrient patterns discussed by Zentara \& Kamykowski (1977). Silicic acid excess occurs off Southeast Asia and may be related to the high regional rainfall/river outflow or the turbulence associated with the complex geography. Regions of nitrate excess appear related to sills (the mouth of the Sea of Okhotsk, the Bering Straits and the Denmark Straits), zones of deep convection (the Denmark Straits and the mouth of the Persian Gulf) as described by Killworth (1983), or coastal upwelling (Peru, Northwest Africa and Southwest Africa) as discussed in Richards (1981). The most spatially coherent and most complex region of contrasting occurrences of nitrate or silicic acid excess in the world ocean occurs south of the southern Subtropical Convergence. The continuity of the GEOSECS pattern of actual or extrapolated nitrate excess in all sectors of the Southern Ocean north of the Antarctic Divergence (Fig. 1) is confirmed. The silicic acid excess reported by Zentara \& Kamykowski (1981) in the Ross Sea also occurs in the Weddell Sea. These areas correspond to regions that Killworth (1983) has identified as deep convection zones and source zones of Antarctic Bottom Water. If this association is totally consistent, then a similar nutrient trend should occur off the Amery Ice

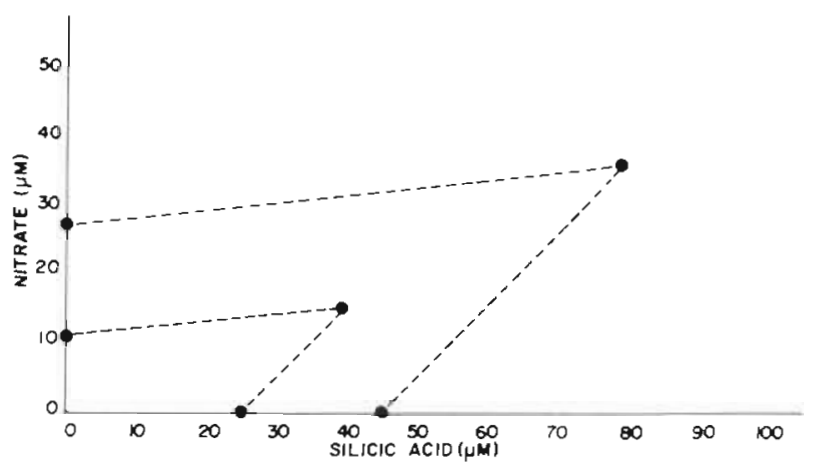

Fig. 4. Hypothetical plot showing influence of both initial high nutrient concentration and slope on the value of the intercepts on the $\mathrm{y}$ or $\mathrm{x}$ axes

Shelf. The patterns of nitrate excess shown in Fig. 3 provide a coherent analysis of the regions in the world ocean where silicic acid may limit diatom growth. Zentara \& Kamykowski $(1977,1981)$ have discussed the implications of silicic acid limitation for phytoplankton succession and for food web structure.

The previous discussion of Fig. 3 has emphasized physical correlations with the intercept patterns. Since upper ocean characteristics are the main focus, chemical and biological processes strongly interact with the physical environment to produce the nitrate versus silicic acid signature characteristic of a given water column at a given time. Zentara \& Kamykowski (1981) have discussed some of these interactions as applied to the Southern Ocean, especially in terms of a reported diatom abundance south of the Polar Front as observed in the plankton (Hasle 1956, 1969) or in the sediments (Sverdrup et al. 1942) and the decreased biogenic silica dissolution rate at lower temperatures (Lawson et al. 1978, Kamatani 1982). Increasing biological information from the Southern Ocean supports the development of a more detailed discussion of the complex nitrate versus silicic acid patterns that occur in this region.

Fig. 4 provides a conceptual framework for more fully interpreting the intercept data in Fig. 3 in terms of processes. The intercept value on either the nitrate or the silicic acid axis depends both on the concentrations of nitrate and silicic acid at the base of the photic zone, and on the slope ( $\Delta \mathrm{N} / \Delta \mathrm{Si}$ ) according to which these 2 nutrients mutually decline in the upper ocean. The following discussion will examine the patterns of these 2 aspects of the nitrate versus silicic acid regression analysis in the Southern Ocean.

Fig. 5 provides an enlargement of the Southern Ocean intercept patterns in Fig. 3. The intercept ranges are further divided into subgroups $(10<\mathrm{nu}-$ trient $<20 \mu \mathrm{M}$; nutrient $>20 \mu \mathrm{M}$ ) to clarify the spatial patterns. The greatest nitrate excesses (left map) occur around the Polar Front and tend to decline toward 


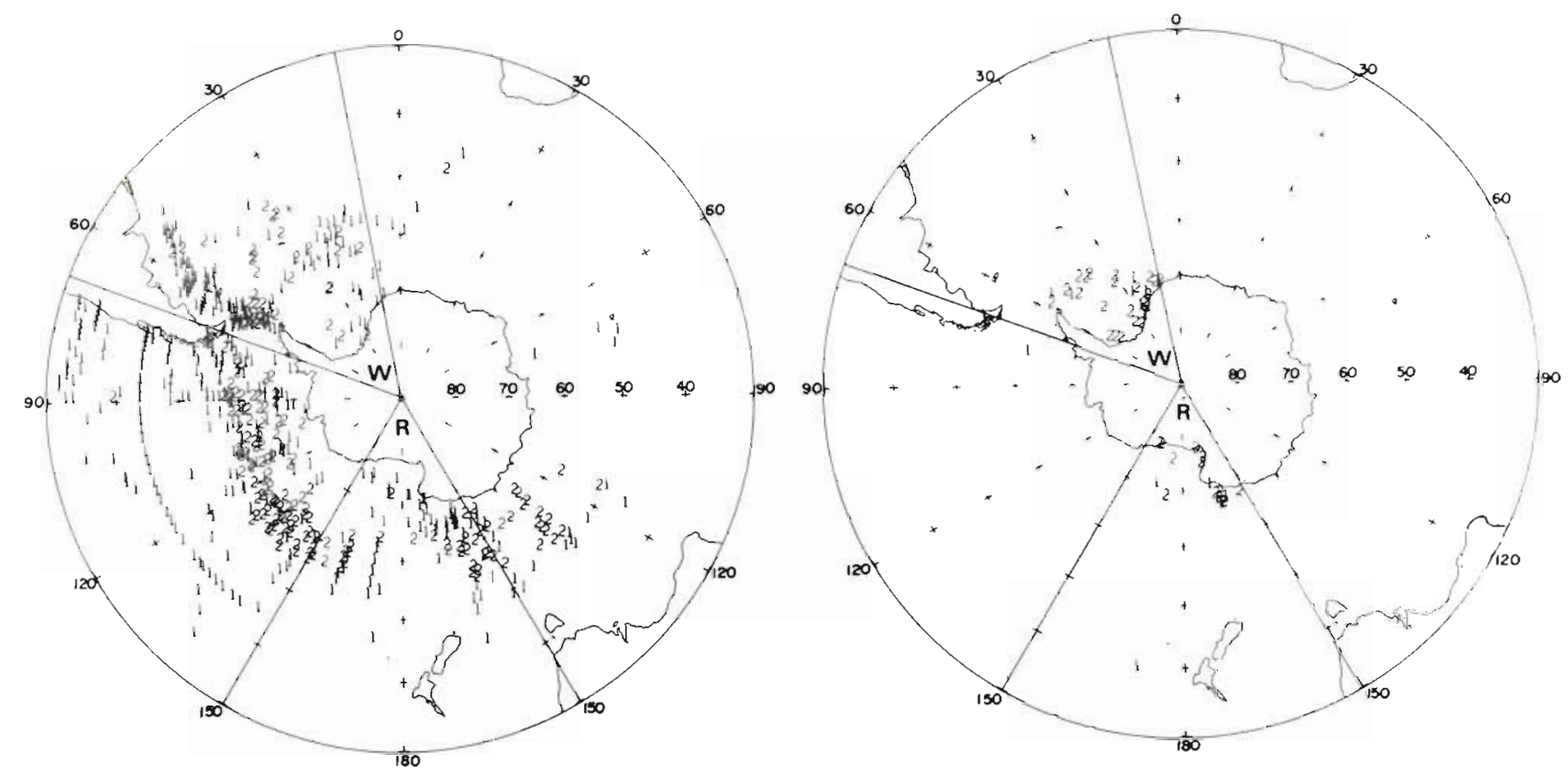

Fig. 5. An expanded view of nitrate versus silicic acid intercept patterns in the Southern Ocean from Fig. 3. The symbols 1 and 2 respectively represent the intercept intervals $10 \mu \mathrm{M}<(\mathrm{N}$ or $\mathrm{Si})<20 \mu \mathrm{M}$ and ( $\mathrm{N}$ or $\mathrm{Si})>20 \mu \mathrm{M}$ for nitrate (left) or silicic acid (right). The 2 sectors Ross Sea (R) and Weddell Sea (W) are the object of a latitudinal percentile analysis

Antarctica. This pattern of decreasing nitrate excess is continued by the occurrence of silicic acid excesses (right map) in the Ross Sea and the Weddell Sea. The amount of nitrate excess appears to decrease east of the Drake Passage. This pattern may be related to the influx of North Atlantic Deep Water east of the Drake Passage and to the transport of the resulting surface water (Pickard 1963) to the east as the Circumpolar Current progresses around Antarctica. A more detailed discussion of meridional influences, however, requires a more refined temporal and spatial (especially with depth) analysis than is presently available. The 2 sectors radiating from the Ross Sea and the Weddell Sea were selected for percentile analysis of latitudinally grouped data. To further minimize the spatial and temporal variability affecting the latitudinal groupings, the data considered within each sector were limited to that collected from the upper $100 \mathrm{~m}$ of the water column from January through March.

Fig. 6 and 7 show the 10th, 50th, and 90th percentiles for latitudinally grouped nitrate and silicic acid concentrations for the Ross Sea and Weddell Sea sectors, respectively. Nitrate and silicic acid concentrations generally exhibit high values south of $60^{\circ} \mathrm{S}$. In agreement with Bogoyavlenskiy (1967), Berger (1970), Broecker \& Peng (1982) and Le Corre \& Minas (1983),
Fig. 6. Smoothed fits to the 10th, 50 th and 90th percentiles of nitrate and silicic acid concentrations for $1^{\circ}$ latitudinal groupings of stations in the Ross Sea sector in the upper $100 \mathrm{~m}$ during January to March. X: values of the 50 th percentiles fitted by the solid line
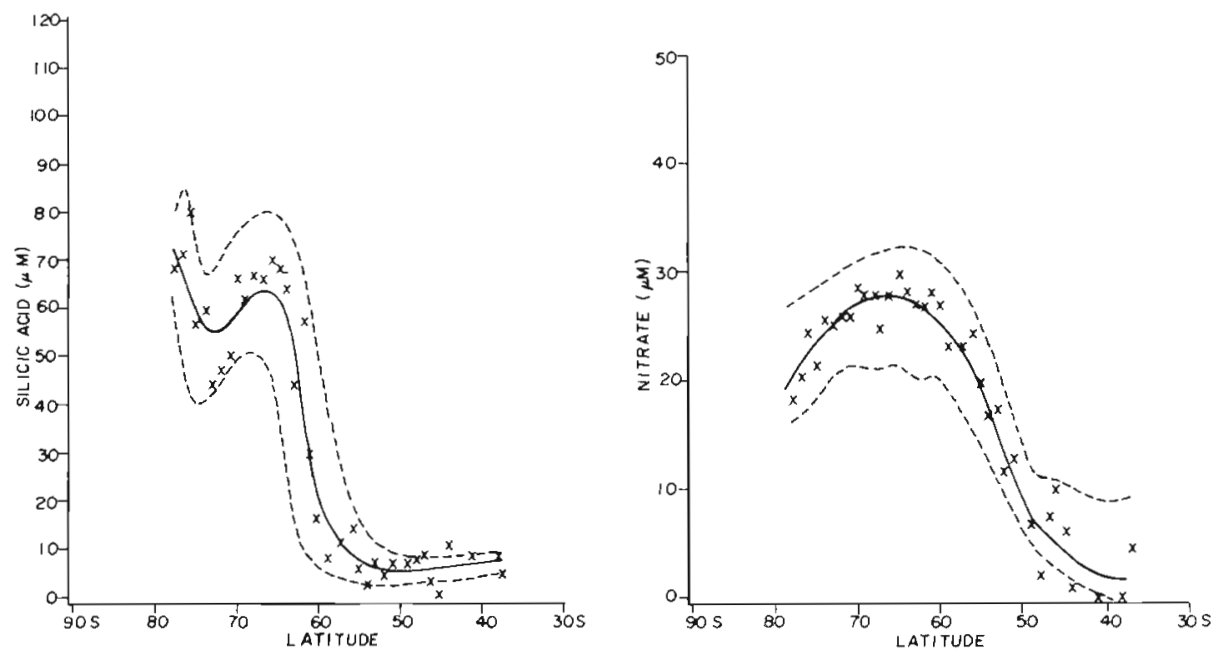


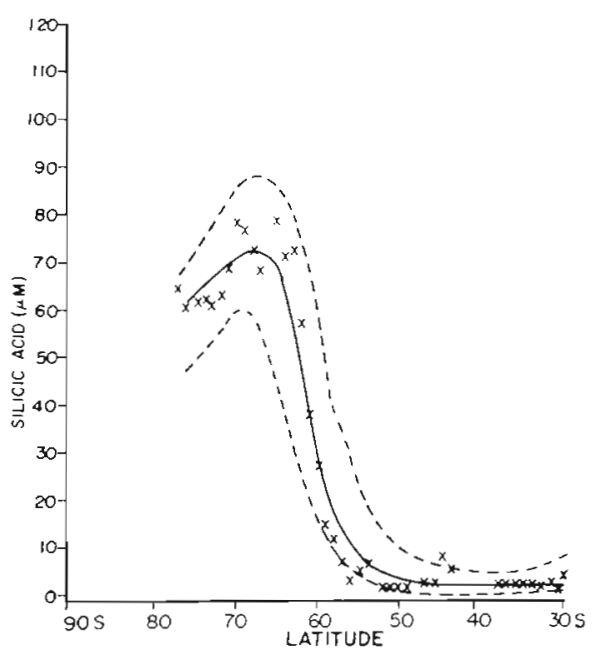

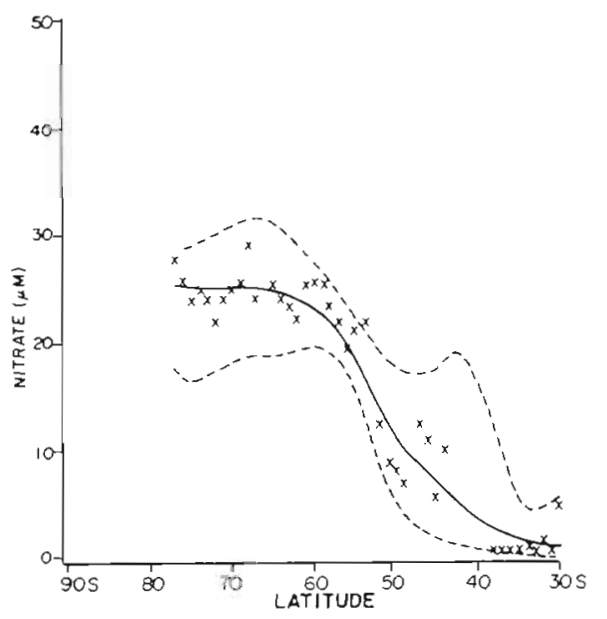

Fig. 7. Same as Fig. 6 for the Weddell Sea sector

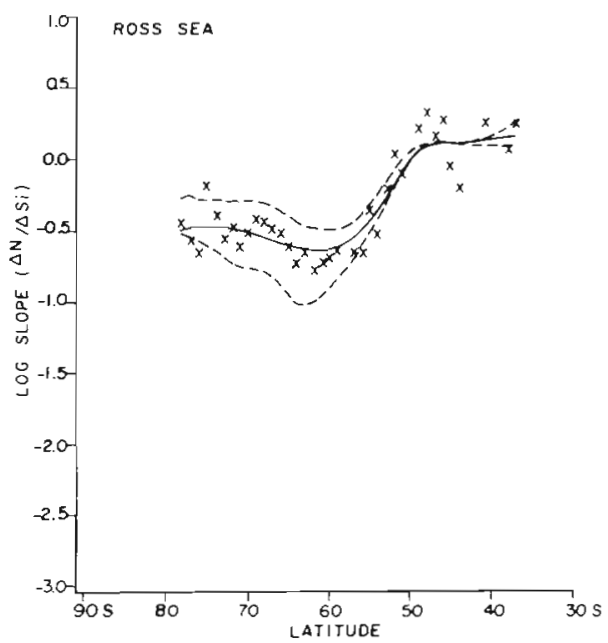

silicic acid concentration undergoes a rapid decline with decreasing latitude between 65 and $55^{\circ} \mathrm{S}$, and nitrate concentration undergoes a more gradual decline with decreasing latitude between 65 and $40^{\circ} \mathrm{S}$. The silicic acid decline levels off north of the Polar Front and the nitrate decline levels off north of the Subtropical Convergence.

The $100 \mathrm{~m}$ depth limit applied to the data in Fig. 6 and 7 was selected as sub-euphotic zone and as a compromise estimate of the depth of vertical winter mixing of surface waters. This latter estimate is based on the observation by Gordon (1971) that the $90 \%$ oxygen saturation level, a measure of the base of free vertical convection, rarely exceeds $200 \mathrm{~m}$ south of the Polar Front and is less than $100 \mathrm{~m}$ in the stable surface waters of the southern section of the Southeast Pacific Basin and the northern Weddell Sea. With these assumptions in mind, the 90th percentiles in Fig. 6 and 7 , as a measure of the nutrient concentrations at $100 \mathrm{~m}$ in January to March, represent the nitrate and silicic acid concentrations throughout the euphotic zone at the beginning of the growth season (Jennings et al 1984).

Fig. 8 shows the 10th, 50th, and 90 th percentiles of the latitudinally grouped log slopes for the Ross Sea and Weddell Sea sectors. The slopes tend to increase somewhat to the south of $60^{\circ} \mathrm{S}$ and to increase significantly to the north of $60^{\circ} \mathrm{S}$. Log slopes south of $60^{\circ} \mathrm{S}$ are generally less than 0 and $\log$ slopes north of $50^{\circ} \mathrm{S}$ are generally greater than 0 .

Fig. 9 combines the 90th percentile of nutrient concentrations from Fig. 6 and 7 with the 10th and 90th percentiles of slopes from Fig. 8 for selected latitudes to form a representative envelope of regression relations and resulting intercepts for the 2 sectors. South of $60^{\circ} \mathrm{S}$ the intercept changes primarily result from changing slopes in the nitrate versus silicic acid relation. North of $60^{\circ} \mathrm{S}$, both latitudinally changing nutrient concentrations at the base of the euphotic zone and changing slopes affect the intercept values.

Since the slope of the nitrate versus silicic acid regression is a dominant variable contributing to the 

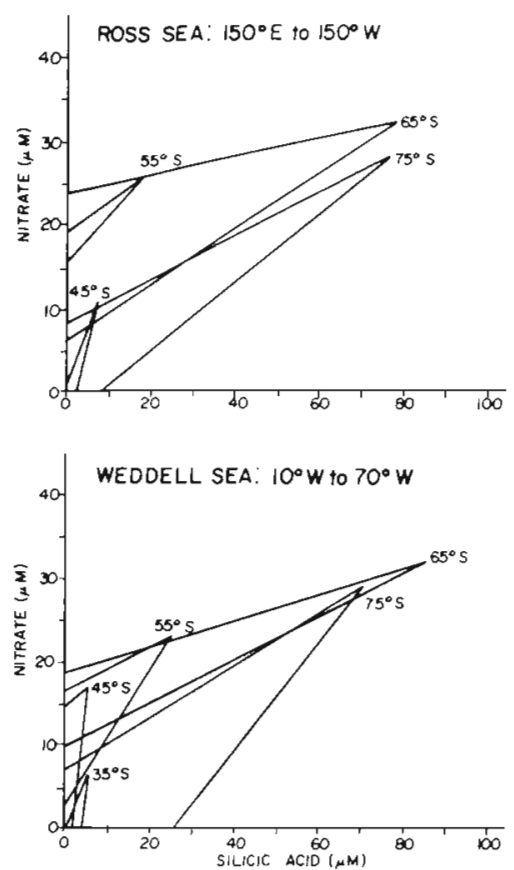

Fig. 9. Families of nitrate versus silicic acid regression relations for selected latitudes based on the 90th percentiles from Fig. $6 \& 7$ and the 10th and 90th percentiles from Fig. 8 for the Ross and Weddell Sea sectors

intercept patterns in the Southern Ocean, Fig. 10 depicts the geographical pattern of the slopes south of $30^{\circ} \mathrm{S}$. For the region south of $60^{\circ} \mathrm{S}$, intercepts on the silicic acid axis generally result from log slopes greater than -0.5 (symbol 0 ) and intercepts on the nitrate axis generally result from log slopes less than -0.5 (symbol
$X)$. The elucidation of the pattern of log slopes shown in Fig. 10 requires a consideration of the various biological and chemical processes that determine the measured concentrations of nitrate and silicic acid within the euphotic zone throughout the growth season.

Fig. 11 summarizes various processes that affect nitrate and silicic acid concentrations. Although this same simple flow diagram could apply to any latitude, the following discussion will emphasize these pathways as they relate to Southern Ocean dynamics south of the Polar Front. This focus is based on the continuous presence of nitrate and silicic acid in the euphotic zone throughout the growth season in most regions south of the Polar Front. After the depletion of nitrate or silicic acid in the water column, many of the processes depicted in Fig. 11 no longer leave a record in the nutrient profiles. The numbers in parentheses in the following discussion refer to corresponding numbers in Fig. 11.

Toward the beginning of the growth season at a given geographic location (or for a dynamically continuous band relative to the Polar Front) in the Southern Ocean, nitrate and silicic acid are at their highest seasonal concentrations (1) throughout the euphotic zone. Initial growth (2) by various phytoplankton classes utilizes the available nitrate as the nitrogen source and diatoms additionally take up some of the available silicic acid. Sakshaug \& Holm-Hansen (1984) have noted that fairly large centric diatoms or chains of them or colonies of the haptophyte Phaeocystis pouchetii usually dominate pelagic blooms south of the Polar
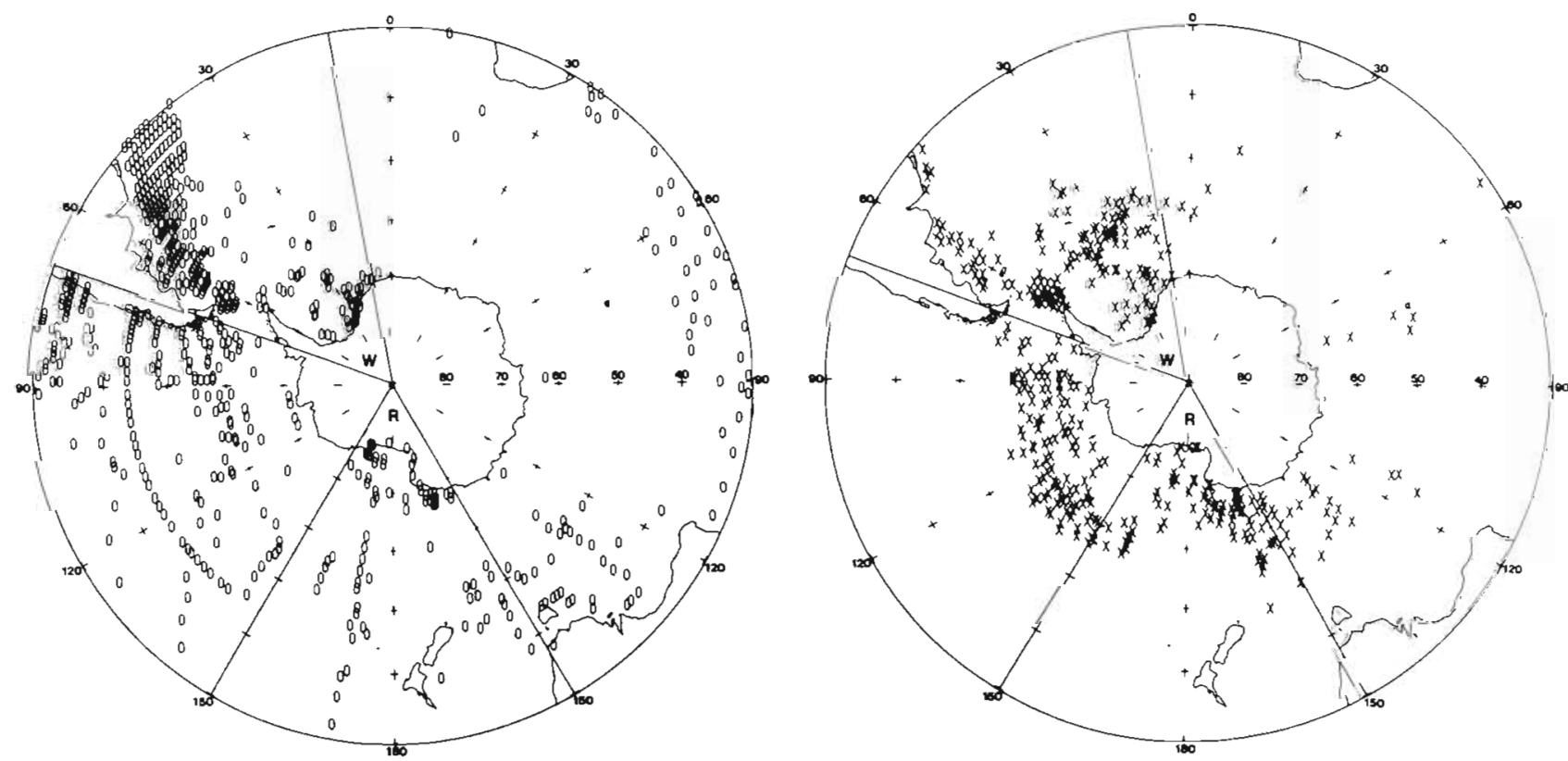

Fig. 10. Polar stereographic views of the nitrate versus silicic acid log slope patterns in the Southern Ocean. The Ross Sea ( $R$ ) and Weddell Sea (W) sectors are marked. The symbols 0 and $X$ respectively represent log slopes greater than -0.5 and less than -0.5 


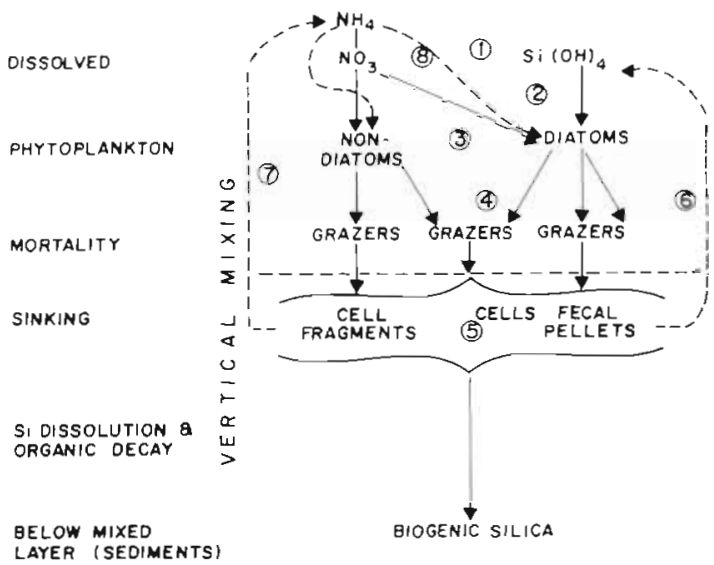

Fig. 11. Flow chart of processes that affect the nitrate and silicic acid concentration in the upper ocean. The numbers refer to discussion statements in the text

Front and that nanoplankton may constitute more than $50 \%$ of the phytoplankton biomass under the more common non-bloom conditions. Assuming that a progression from a diatom bloom to a non-bloom with less diatom representation is a normal occurrence, then the character of the nitrate and silicic acid profiles may be determined by the nitrogen sources available at the time of the diatom bloom. Antarctic diatoms are believed to utilize nitrogen and silicon in an atom ratio (3) of about $1 \mathrm{~N}$ to 2 or $3 \mathrm{Si}$ (Jennings et al. 1984. Sakshaug \& Holm-Hansen 1984). This diatom uptake ratio based on nitrate and silicic acid corresponds to log slopes of -0.3 to -0.5 such as those that occur in some parts of the Ross Sea and Weddell Sea in association with silicic acid intercepts. Jennings et al. (1984) have argued that the silicic acid profile corrected for biogenic silica dissolution can be used in the Weddell Sea to estimate diatom production if winter water silicic acid concentrations are known. The development of a grazing community at high latitudes (4) may be rapid as in the North Pacific or may occur after a time lag as in the North Atlantic (Heinrich 1962). Furthermore, the grazing community may develop at different rates for different components of the phytoplankton community distinguished by class or size. The grazing community can significantly affect how the relation between nitrate and silicic acid develops as the growth season progresses (Le Corre \& Minas 1983). For silicic acid, diatom skeletons may sink from the euphotic zone (5) as whole cells, cell fragments or in fecal pellets depending on how the phytoplankter dies and how it is mechanically or chemically treated at death. The sinking rates of these different particles can range over several orders of magnitude. For whole phytoplankton, Smayda (1970) has shown that growing cells sink more slowly than senescent cells and that cells with diameters from 1 to $1000 \mu \mathrm{m}$ respectively sink from 0.01 to $100 \mathrm{~m} \mathrm{~d}^{-1}$. Representative fecal pellets from copepods and euphausiids sink at sizedependent rates from 10 to $1000 \mathrm{~m} \mathrm{~d}^{-1}$ (Komar et al. 1981). These various sinking rates interact with vertical water motion (Titman \& Kilham 1976) to determine the residence time of detrital biogenic silica in the euphotic zone. The dissolution rate of detrital biogenic silica (6) depends on the diatom species, particle surface area (feeding breakage), chemical exposure (i.e. acid in grazer guts), and temperature (dissolution rate increases $2.27 \times$ per $10 \mathrm{C}^{\circ}$ ) (Kamatani 1982). Net particle sinking rates and detrital biogenic silica dissolution rates interact to yield the silicic acid renewal that characterizes a geographic region. In the Southern Ocean where euphausiid fecal pellets sink rapidly and cold temperatures depress the dissolution rates of biogenic silica, Nelson \& Gordon (1982) have estimated that only about 30 to $40 \%$ of the biogenic silica fixed in the euphotic zone dissolves in this layer. For nitrate, grazers sequester a portion of the nitrogen from their food into their biomass and excrete (7) a portion in feces and urine in reduced forms (i.e. ammonia). The release of the feces nitrogen to the euphotic zone depends on the interaction between net particle sinking rates, and on the bacterial decomposition rates within and diffusion rates from the fecal pellet. The release of the more significant urine (or metabolic) nitrogen depends on the grazer population density, grazer metabolic rates and the residence time of the grazers in the euphotic zone. El-Sayed (1984) has described the profound effect that grazing by krill can have on the phytoplankton standing crop. Significant ammonia release can result from such intense grazing. Also, Sakshaug \& Holm-Hansen (1984) have reported that about a third of the nanoplankton biomass consists of heterotrophic organisms that can contribute to the flux of ammonia. Since marine nitrifying bacteria are photoinhibited at light intensities above $1 \%$ sunlight, released ammonia is not readily converted to nitrate in the euphotic zone (Olson 1981). Since phytoplankton generally prefer ammonia over nitrate as a nitrogen source (McCarthy 1981), a sufficient flux of ammonia into the euphotic zone due to rapid development of a grazing community may support silicic acid utilization by diatoms (8) with little corresponding nitrate utilization. As shown in Fig. 11, the ammonia source for the diatoms may come from grazing on either diatoms or non-diatoms. In the Southern Ocean, Olson (1980), Koike et al. (1981), Glibert et al. (1982) and HolmHansen et al. (1983) have observed that ammonia accounts for 40 to $85 \%$ of the utilized nitrogen in the euphotic zone. Since nitrate and silicic acid generally do not deplete over most of the growth season south of $60^{\circ} \mathrm{S}$, the nitrogen recycling throughout the water column is continuously recorded in the relative utilization 
of nitrate and silicic acid as long as significant diatom activity occurs in the water column. As the bloom ends and diatoms become smaller and rarer, they may no longer dominate the nitrogen uptake, and silicic acid concentrations decrease more slowly. If nitrate is the dominant nitrogen source under non-bloom conditions, nitrate concentration probably declines very slowly due to relatively low rates of primary production that occur in non-bloom conditions (Sakshaug \& Holm-Hansen 1984). Ammonia, however, is more likely to be the dominant nitrogen source under nonbloom conditions due to rapid nitrogen recycling among the nanoplankton (Glibert et al. 1982). This situation will further retard additional changes in nitrate concentration. The conceptual framework in Fig. 11 assumes that vertical mixing does not change the euphotic zone signature of nutrient uptake during the growth season.

In summary, if nitrate is the dominant nitrogen source during a diatom bloom in the Southern Ocean, nitrate concentrations will decline in association with silicic acid in a way that is balanced against the uptake ratio of $\mathrm{N}$ to $\mathrm{Si}$ by diatoms and by the biogenic silica dissolution rate. If ammonia is the dominant nitrogen source in a diatom bloom in the Southern Ocean, nitrate concentrations will decline more slowly than expected from the uptake ratio of $N$ to $\mathrm{Si}$ by diatoms and from a consideration of the biogenic silica dissolution rate (Glibert et al. 1982, Le Corre \& Minas 1983). Fig. 12 demonstrates this effect by comparing 2 cases with different percentages of ammonia contribution ( 40 and $85 \%$ ) to the nitrogen utilized by the diatoms. Both cases assume that $31 \mu \mathrm{M}$ nitrate and $78 \mu \mathrm{M}$ silicic acid initially occur throughout the euphotic zone, that diatoms are the only phytoplankton, that they require 1 nitrogen atom for every 2.5 silicon atoms (Jennings et al. 1984), that $30 \%$ of the biogenic silica dissolves in the euphotic zone (Nelson \& Gordon 1982) and that nitrate is not regenerated in the euphotic zone (Olson 1981). Vertical mixing is not considered in order to emphasize the biological effects. Each case begins with the first $10 \mu \mathrm{M}$ of upper euphotic zone silicic acid requiring $4 \mu \mathrm{M}$ of upper euphotic zone nitrate. Subsequent silicic acid utilization throughout the euphotic zone is supported by either 40 or $85 \%$ ammonia. These cases emphasize the sensitivity of the silicic acid versus nitrate regression lines (intercepts and slopes) to diatom growth and nutrient regeneration in the region south of the Polar Front. The intercepts under $40 \%$ ammonium utilization tend to fall on the silicic acid axis and intercepts under $85 \%$ ammonium utilization tend to fall on the nitrate axis. In these sample cases, silicic acid changes in the water column record diatom growth and the corresponding nitrate changes record nitrogen recycling as recently discussed by Jennings et
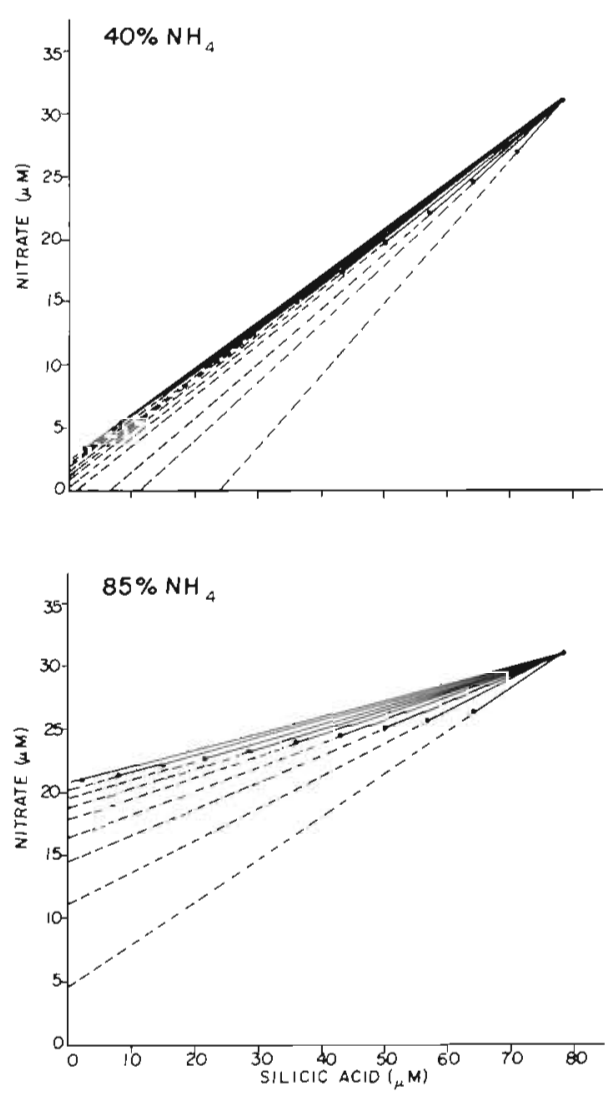

Fig. 12. Hypothetical time course plots of the changing nitrate versus silicic acid relations under $40 \%$ and $85 \%$ ammonia utilization in water columns south of $60^{\circ} \mathrm{S}$

al. (1984) in the Weddell Sea. The cases also demonstrate that the intercepts and slopes under a given set of diatom growth and nutrient recycling conditions change with time. As the growth season progresses, the effect of the nutrient recycling becomes more dominant. The successive slopes of the family of regression lines in either case provide an estimate of the average amount of nutrient recycling that has occurred in that water column up to the time when the nutrient profile is determined. The final slopes (log slopes) in each case are, respectively, $40 \%: 0.36$ $(-0.44) ; 85 \%: 0.13(-0.89)$. Adjusting the final slopes for $\mathrm{N} / \mathrm{Si}$ uptake ratio and biogenic silica dissolution yields average ammonia contributions of 37 and $77 \%$ respectively. Recall that this estimate includes the initial phytoplankton growth on nitrate as the sole nitrogen source that initiated each case. The inclusion of non-diatom nutrient uptake would contribute to the underestimation of nutrient recycling, as nitrate is utilized independently of silicic acid.

The previous discussion demonstrates that the patterns in Fig. 5 and 9 can be used to examine nitrogen recycling south of the Polar Front. A static interpretation of the patterns suggests that nitrogen recycling is 
very important to phytoplankton growth in the Southern Ocean especially near the Polar Front (Sakshaug \& Holm-Hansen 1984) and less important towards the ice edge or the Antarctic continent in agreement with Biggs et al. (1983). This latitudinal gradient, however, can also be interpreted in terms of growth season maturity as demonstrated by the time course of the nutrient profile development in Fig. 12. This means that early growth season measurements just south of the Polar Front may not exhibit such extreme values of nitrate excess as may be observed later in the growth season. North of the Polar Front, the decrease in silicic acid concentration and the scarcity of diatoms in the phytoplankton community (Hasle 1956, 1959) contribute to increasing nitrate versus silicic acid slopes and decreasing nitrate intercepts in Subantarctic Surface Water (Fig. $5 \& 10$ ).

The application of the processes in Fig. 11 to nitrate versus silicic acid relations in other parts of the world ocean (Fig. 1 \& 3) requires regional evaluations of how to weight the various pathways. One dichotomy that clearly must be considered is the distribution of nitrate and silicic acid concentrations relative to the euphotic zone. Regions where detectable concentrations of nitrate and silicic acid occur within the euphotic zone such as high latitudes or many coastal regions (especially upwelling zones) have nutrient profiles that are affected by light availability, proximate phytoplankton growth and ammonia uptake interactions. Regions where detectable concentrations of nitrate and silicic acid occur primarily below the euphotic zone have nutrient signatures that are derived in low light and removed from phytoplankton growth and from ammonia uptake interactions (Harrison 1980). The weighting of the processes in Fig. 11 is obviously different in these 2 cases. Other variables like the diatom contribution to the phytoplankton community, diatom uptake ratios of $\mathrm{N} / \mathrm{Si}$, the temperature kinetics of biogenic silica dissolution and density dependent sinking rates of particles provide additional complexities.

\section{CONCLUSIONS}

Nitrate and silicic acid concentrations in the upper world ocean exhibit a pattern that results from the nutrient character of the water transported into a region as a result of deep and surface circulation and from the local weighting of various biological and chemical pathways. Several regions exhibit silicic acid depletion that can inhibit diatom growth in the presence of excess nitrate. In the Southern Ocean south of the Polar Front, upwelling and convection combine to maintain high, spatially uniform, winter surface nutrient concentrations in the circumpolar flow. Large, occasionally dominant diatom populations, slowed biogenic silica dissolution rates due to cold temperatures, and variable but often significant ammonia availability due to grazing activity in the presence of high nitrate concentration combine to yield diverse nutrient signatures as the growth season matures at a geographic location. The slopes of the nitrate versus silicic acid regression relations for a given time and place are influenced by the average amount of nitrogen recycling to that point in the growth season. The ability to extract this information on nitrogen recycling from a given nutrient profile depends on how well the total phytoplankton nitrate uptake is represented by silicic acid uptake during the growth season. Available data suggest that the slopes of the nitrate versus silicic acid regression lines are useful for monitoring nitrogen recycling. The Southern Ocean south of the Polar Front exhibits a symmetrical circumpolar pattern in nitrate and silicic acid relations possibly based on growth season maturity but is geographically distorted by land masses, deep water circulation and surface currents. The interpretation of nitrate and silicic acid profiles in other regions of the world ocean requires a detailed analysis of the chemical and biological pathways that influence these nutrients.

Acknowledgements. This material is based on research supported by the National Science Foundation under Grant No. OCE 81-00423. Several people contributed to the project including several consultants associated with NODC, the Statistics Department and the Computer Center at NCSU, the SAS Institute and the SIO GEOSECS data group. D. Myrick was especially helpful throughout the study

\section{LITERATURE CITED}

Andrews, W. R. H., Hutchings, L. (1982). Upwelling in the Southern Benguela Current. In: Angel, M. V., O'Brien, J. (ed.) Prog. Oceanogr. 9: 1-82

Berger, W H. (1970). Biogeneous deep-sea sediments: fractionation by deep sea circulation. Bull. geol. Soc. Am 81 1385-1402

Biggs, D. C., Holm-Hansen, O., Koike, I. (1983). The fate of phytoplankton blooms in the southern Ross Sea: carbon and nitrogen dynamics over a deep, high latitude austral continental shelf. EOS Trans. Am. geophys. Un. 64: 1099 (Abstract)

Bogoyavlenskiy, A. N. (1967). Distribution and migration of dissolved silica in oceans. Int. Geol. Rev. 9: 133-153

Broecker, W S., Li, Y H. (1970). Interchange of water between the major oceans. J. geophy. Res. 75: 3545-3552

Broecker, W. S., Peng. T H. (1982). Tracers in the sea. Eldigio Press, Palisades, New York

Craig, H., Turekian, K. K (1981). The GEOSECS program: 1976-1979. Earth Planet. Sci. Lett. 49: 263-265

Dugdale, R. C. (1972). Chemical oceanography and primary productivity in upwelling regions. Geoforum 11: 47-61

El-Sayed, S. (1984). Productivity of Antarctic waters - a reappraisal. In: Holm-Hansen, O., Bolis, L., Gilles, R. (ed.) 
Marine phytoplankton and productivity. Springer-Verlag, Berlin, p. 19-34

Friederich, G. E., Codispoti, L. A. (1979). On some factors influencing dissolved silicon distribution over the northeast African shelf. J. mar Res. 37. 337-353

Friederich, G. E., Codispoti, L. A. (1981). The effects of mixing and regeneration on the nutrient content of upwelling water off Peru. In: Richards, F. A. (ed.) Coastal upwelling. Am. geophys. Un., Washington, D.C., p. 221-227

Glibert, P. M., Biggs, D. C., McCarthy, J. J. (1982). Utilization of ammonium and nitrate during austral summer in the Scotia Sea. Deep Sea Res. 29: 837-850

Gordon, A. L. (1971). Oceanography of Antarctic waters. In: Reid, J. L. (ed.) Antarctic oceanography I. Antarct. Res. Ser. 15: 169-201 Am. geophys. Un.

Gordon, A. L., Molinelli, E. J., Baker, T. N. (1982). Southern Ocean atlas. Columbia Univ. Press, New York

Harrison, W. G. (1980). Nutrient regeneration and primary production in the sea. In: Falkowski, P. G. (ed.) Primary productivity in the sea. Plenum Press, New York, p. $433-460$

Harrison, W. G., Platt, T., Calienes, R., Ochoa, N. (1981). Photosynthetic parameters and primary production of phytoplankton populations off the northern coast of Peru. In: Richards, F. A. (ed.) Coastal upwelling. Am. geophys. Un., Washington, D.C., p. 303-311

Hasle, G. R. (1956). Phytoplankton and hydrography of the Pacific part of the Antarctic Ocean. Nature, Lond. 177: 616-617

Hasle, G. R. (1969). An analysis of the phytoplankton of the Pacific Southern Ocean: Abundance, composition, and distribution during the Brategg Expedition, 1947-1948. Hvalråd. Skr. 52: 1-168

Heinrich, A. K. (1962). The life histories of plankton animals and seasonal cycles of plankton communities in the oceans. J. Cons. perm. int. Explor. Mer. 27: 15-24

Holm-Hansen, O., Biggs, D. C., Ronner, U. (1983). Nitrogen assimilation by phytoplankton in the Scotia Sea: distribution and uptake of ammonia and nitrate. EOS Trans. Am. geophys. Un. 64: 1090 (Abstract)

Jennings, J. C. Jr., Gordon, L. I., Nelson, D. M. (1984). Nutrient depletion indicates high primary productivity in the Weddell Sea. Nature, Lond. 309: 51-54

Kamatani, A. (1982). Dissolution rates of silica from diatoms decomposing at various temperatures. Mar. Biol. 68: 91-96

Kamykowski, D. (1974). Physical and biological characteristics of an upwelling at a Station off La Jolla, California during 1971. Estuar. coast. mar Sci. 2: 425-432

Killworth, P. D. (1983). Deep convection in the world ocean. Rev. Geophys. Space Phys. 21 1-26

Koike, I., Ronner, U., Holm-Hansen, O. (1981). Microbial nitrogen metabolism in the Scotia Sea. Antarct. J. U.S. 16: 165-166

Komar, P. D., Moore, A. P., Small, L. F. (1981). An analysis of sinking rates of natural copepod and euphausiid fecal pellets. Limnol. Oceanogr. 26: 172-180

Lawson, D. S., Hurd, D. C., Pankrantz, H. S. (1978). Silica dissolution rates of decomposing phytoplankton assemblages at various temperatures. Am. J. Sci. 278: 1373-1393

Le Corre, P., Minas, H. J. (1983). Distribution et evolution des elements nutritifs dans le secteur indien de l'ocean Antarctique en fin de periode estivale. Oceanologica Acta 6: $365-381$
Mc Carthy, J. J. (1981). The kinetics of nutrient utilization. Can. Bull. Fish. Aquat. Sci. 210: 211-233

Minas, H. J., Codispoti, L. A., Dugdale, R. C. (1982). Nutrients and primary production in the upwelling region off Northwest Africa. Rapp. P.-v. Réun. Cons. int. Explor. Mer 180 148-183

Nelson, D. M., Gordon, L. I. (1982). Production and pelagic dissolution of biogenic silica in the Southern Ocean Geochim. cosmochim. Acta 46: 491-501

Olson, R. J. (1980). Nitrate and ammonium uptake in Antarctic waters. Limnol. Oceanogr. 25: 1064-1074

Olson, R. J. (1981). Differential photoinhibition of marine nitrifying bacteria; a possible mechanism for the formation of the primary nitrate maximum. J. mar. Res. 39 : $227-238$

Pickard, G. L. (1963). Descriptive physical oceanography. Pergamon Press, Oxford

Reid, J. L. (1965). Intermediate waters of the Pacific Ocean. The John Hopkins Oceanographic Studies 2: 1-85

Richards, F. A. (1981). Coastal upwelling. Am. geophys. Un., Washington, D.C.

Sakshaug, E., Holm-Hansen, O. (1984). Factors governing pelagic production in Polar Oceans. In: Holm-Hansen, O., Bolis, L., Gilles, R. (ed.) Marine phytoplankton and productivity. Springer-Verlag, Berlin, p. 1-18

SAS Institute Inc. (1982). SAS user's guide: basics. Box 8000 Cary, North Carolina 27511

Smayda, T. S. (1970). The suspension and sinking of phytoplankton in the sea. Oceanogr. mar. Biol. A. Rev. 8: $353-414$

Sokal, R. R., Rohlf, F. J. (1981). Biometry, 2nd ed. W. H. Freeman, and Co., San Francisco

Sverdrup, H. U., Johnson, M. W., Fleming, R. H. (1942). The oceans. Prentice-Hall Inc., Englewood Cliffs, New Jersey

Tilman, D., Kilham, S. S., Kilham, P. (1982). Phytoplankton community ecology: the role of limiting nutrients. Ann. Rev. Ecol. Syst. 13: 349-372

Titman, D., Kilham, P. (1976). Sinking in freshwater phytoplankton. Some ecological implications of cell nutrient status and physical mixing processes. Limnol. Oceanogr. 21: 409-417

Walsh, J. J. (1971). Relative importance of habitat variables in predicting the distribution of phytoplankton of the ecotone of the Antarctic upwelling ecosystem. Ecol. Monogr. 41: 291-309

Warren, B. A. (1981). Deep circulation of the world ocean. In: Warren, B. A., Wunsch, C. (ed.) Evolution of physical oceanography. MIT Press, Cambridge, Massachusetts

Werner, D. (1977). The biology of diatoms. Botanical Monographs 13, Blackwell Scient. Publ., Oxford

Worthington, L. V. (1981). The water masses of the world ocean: some results of a fine-scale census. In: Warren, B. A., Wunsch, C. (ed.) Evolution of physical oceanography. MIT Press, Cambridge, Massachusetts

Wust, G. (1935). Schichtung und Zirkulation des Atlantischen Ozeans. Die Stratosphere. In: Wiss. Ergebn. dt. atlant. Exped. 'Meteor' 1925-1927,6: Part 1, Lief 2, p. 1-180

Zentara, S.-J., Kamykowski, D. (1977). Latitudinal relationships among temperature and selected plant nutrients along the west coast of North and South America. J. mar. Res. 35: 321-337

Zentara, S.-J., Kamykowski, D. (1981). Geographic variations in the relationship between silicic acid and nitrate in the South Pacific Ocean. Deep Sea Res. 28: 455-465 